\title{
Photovoltaic Solar Energy Simulation of Rooftops of a University Campus Buildings in Surabaya, Indonesia
}

\author{
Elieser Tarigan ${ }^{1,3}$, Djuwari ${ }^{1}$, Fitri Dwi Kartikasari ${ }^{2,3}$ \\ \{elieser@staff.ubaya.ac.id ${ }^{1,3}$, djuwari@staff.ubaya.ac.id ${ }^{1}$, fitri_dk@staff.ubaya.ac.id ${ }^{2,3}$ \} \\ ${ }^{1}$ Electrical Engineering, ${ }^{2}$ Informatics Engineering, ${ }^{3}$ Center for Renewable Energy Studies, PSET, \\ University of Surabaya, Jl. Raya Kalirungkut, Surabaya 60292, Indonesia
}

\begin{abstract}
This work simulates and estimates the useful surface area of roof of the buildings of University of Surabaya for photovoltaic (PV) system installation. A representative building is used in simulation to calculate the panel capacity that can be produced by a roof mounted PV with grid-connected system. It was found that about $10,353 \mathrm{~m}^{2}$ of roof top of the university buildings could be used for panels installation. The total capacity of the panels is about 2,030 kWp or 2,03 MWp. The capacity consists of four roof directions, i.e., $630 \mathrm{kWp}, 535 \mathrm{kWp}, 668 \mathrm{kWp}$ and $553 \mathrm{kWp}$ respectively for $\mathrm{NE}, \mathrm{SE}, \mathrm{SW}$ and NW roof directions.
\end{abstract}

Keywords: Solar energy, Photovoltaic, Campus building, Simulation, Rooftops.

\section{Introduction}

Solar energy is one of the most common and inexhaustible renewable energies that plays an increasingly essential role recently. Solar energy in the form of radiation can be directly converted into electricity using photovoltaic (PV) technologies. One of the mostly direct usages of solar energy is conversion from solar to photovoltaic electric energy [1].

The assessment of solar energy potential in a location where PV systems is planned to be installed is required and affects the successfulness of deployment of the PV systems. The potential of energy output much depends directly from the local exposure to sunlight. One aspect that should be considered for evaluating real outcomes of roof mounted PV system investments is architectonic buildings. The aspect includes identification of building roof surfaces (flat and slanted); estimation of number of floors for each building; and shape classification of roofs [2].

Computer simulation techniques can be used to predict of the PV system performance before they are put in place hence reducing materials and installation costs [3]. Substantial research has been conducted on the topic of building rooftop PV installation potential [4]. Quantified the rooftop PV power generation potentials in Southeastern Ontario was reported by Wiginton et al. [5]. Five steps were applied determine available rooftop surface area, i.e., sampling, the geographical division of the region, sampling, deducing the relationship between rooftop area and population, reduction of shading and other uses, and conversion to power and energy outputs. Vardimon [6] reported a study of the useful area of rooftops in Israel. The work was carried out using orthoimages to extract building layer images. The available rooftop area was calculated by using GIS data. It was repotted that $32 \%$ of annual Israel national consumption was equivalent to the annual rooftop PV electricity production. 
Bergamasco et al. [7] studied the assessment of the PV energy potential together with its application to the Pied- mont Region (North-Western Italy). The useful roof area for solar PV system applications was calculated through the analysis of available GIS data.

The objective of this work is to estimate the useful surface area of roof of the buildings of University of Surabaya, specifically for PV panel installation. Further, the work also to calculate the electricity energy that can be produced by a grid-connected PV system if solar panel arrays are mounted on building roofs. A mathematical equation is derived to estimate the unit cost of electricity from a grid connected system under local conditions.

\section{Methodology}

\subsection{Total Surface Area}

At the time this study was conducted, there were 29 permanent buildings of campus University of Surabaya. The name and the location of the buildings are shown in Figure 1 as taken from Google EarthTM. When it is not specifically named, the first letter of the name for each building is from initial faculty name, for example, $E$ for economic faculty, $F$ for pharmacy (farmasi in bahasa Indonesia) etc. Therefore building EA refers to building A of economic faculty and building FB refers to building B of faculty of pharmacy, etc. The building are being used for various different academically purposes such class rooms, offices, library, laboratories, canteens. In addition, there are some non permanent and semi permanent buildings and they are excluded in this study. The 29 considered buildings in this study consist of storey buildings with conditions as shown in the Table 1 . The total surface area of the campus and the roof of the buildings are determined by using Polygon feature (measuring the distance or area of a geometric shape ) of Google Earth TM.

All of the buildings are oriented/tilted 450 to the main geographical direction that have the roofs direction each to North East (NE), South East (SE), South West (SW), and North West (NW) as shown in Figure 1 and Figure 4. The type of the roof is mainly Hip roof and subtype Gablet Roof or Dutch Roof [8] which have four sides and direction as shown in Figure 2. The roofs are installed with a tilt angle of 350 relative to horizontal.

For the area of the roof, measurements were conducted for each side according to the geographical orientation of the roof sides. This is important as the solar panel orientation in the simulation is assumed to follow the roof orientation.

Table 1. Storey Building at University of Surabaya

\begin{tabular}{ll}
\hline Storey Building & Buildings \\
\hline Two-storey & EB, FA, TA, PA, International \\
& Village, Canteen \\
Three-storey & TB,ED \\
Four-storey & EA, EC, FB, FC, FD, \\
& FE,HA,HB,TC, TD, TE, \\
& TF,PB, PC, PD, PE \\
Six-storey & FF, FG, Library, TG \\
\hline
\end{tabular}




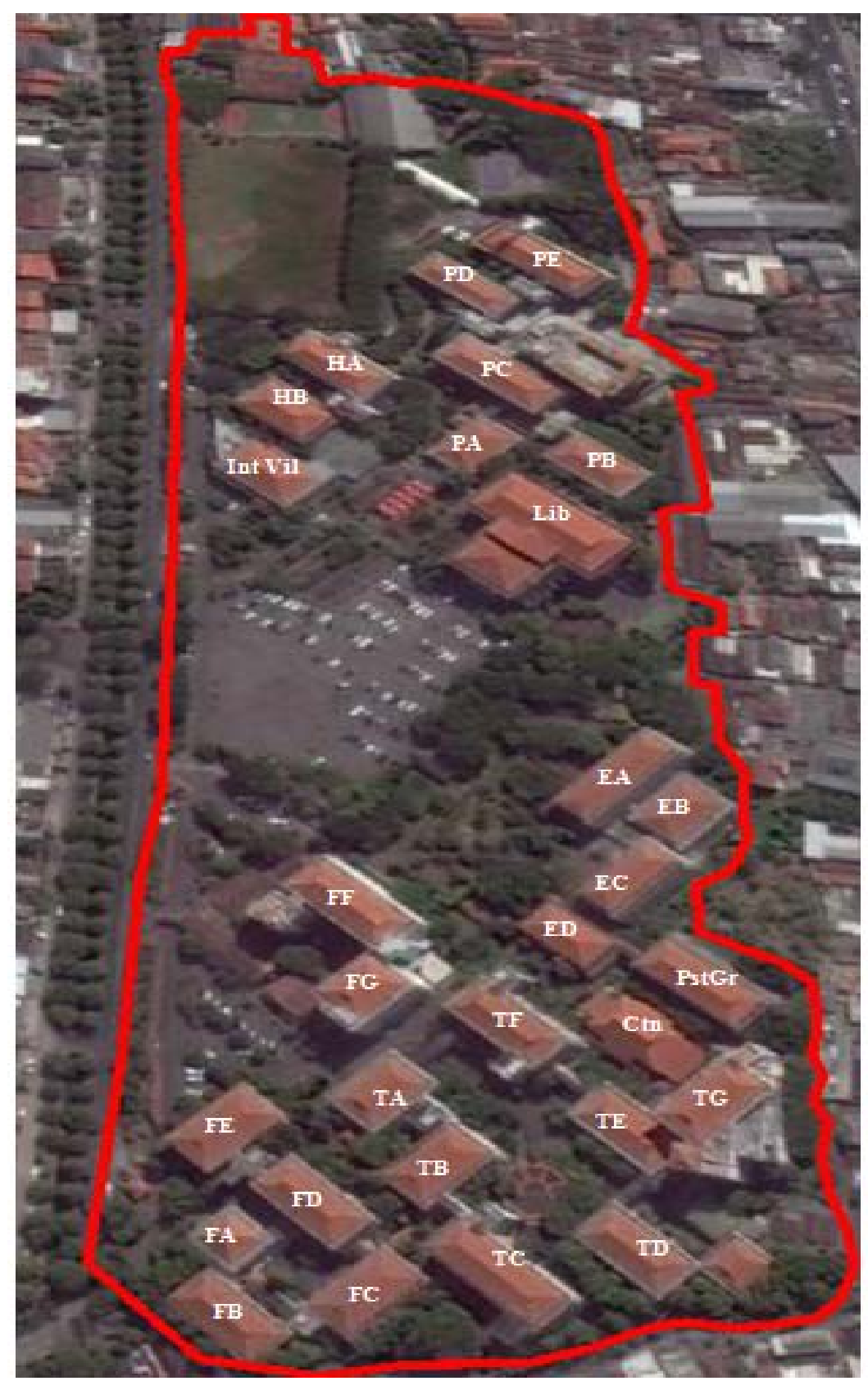

Fig. 1. Map of buildings of University of Surabaya generated from Google Earth ${ }^{\mathrm{TM}}$ 

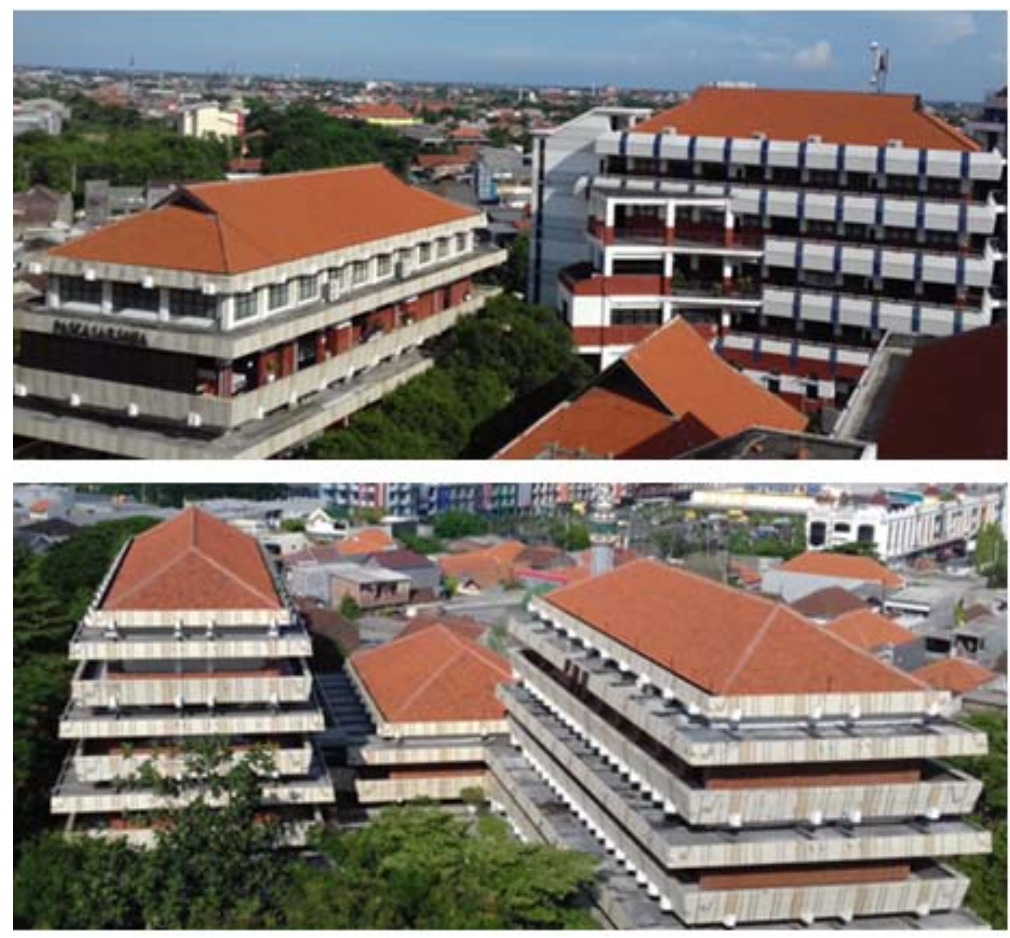

Fig. 2. Gablet roof (upper) and Hip roof (lower) types of University of Surabaya buildings

\subsection{Useful Roof Surface Area}

The useful surface area of the roof where PV system could be installed was determined by considering the geometrics characteristics of a building. The area was obtained by selecting library building as representative sample of the campus buildings under study. The area was calculated from maps generated from Google EarthTM and exported and scaled with Google Sketch up software application. Further, solar panels with various speciations were applied and simulated to the roof to determined mean percentage of effective surface area after eliminating interfering elements. The real picture and the generated picture with roof panels installed of the representative building is shown in Figure 3.

\subsection{Shading Factor}

When come into real installation, the detail of real building need to further studied specifically for each building. The considerations are including shading factor due to surrounding obstruction that could come from elevator shafts, HVAC, antennas, as well as other elements that could interfere with the PV system. Considering the very small surrounding obstruction within the campus area, for the university buildings in this work, the energy lost due to shading factors is calculated based on value proposed by previous similar work [9], i.e. $2 \%$ of total energy production. 

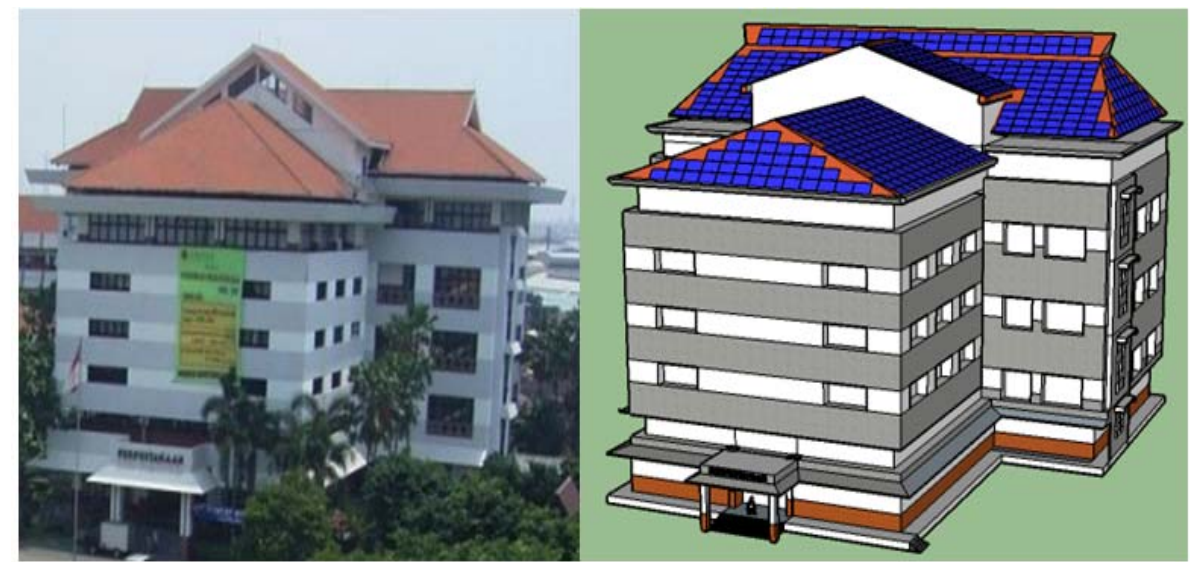

Fig. 3. Library building as representative building used in simulation

\subsection{Simulation}

Grid connected PV system were simulated with the roof-mounted PV panels aligned to the roof orientation. Theoretical sitting of PV panels for different building orientations are graphically shown in Figure 4. Each side of the roofs surface is used as much as possible for mounting of chosen PV panels. Solar energy potential is carried out using solar SolarGISpvPlanner following previous study[10].

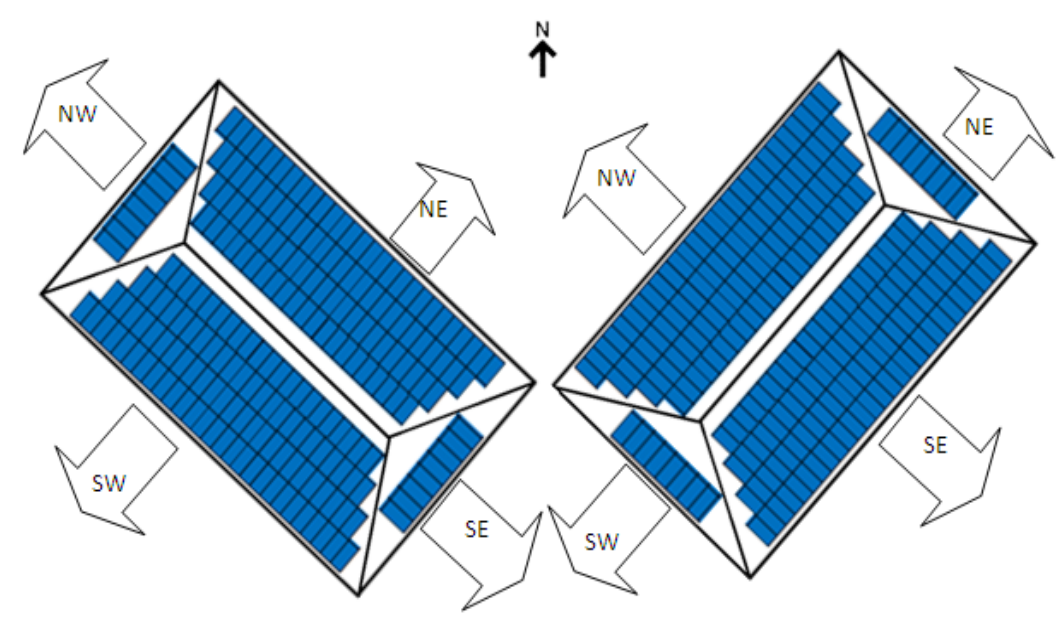

Fig. 4. Theoretical sitting of PV panels for different building orientation

Simulation for grid connected PV system is conducted for representative building (library building) to estimate PV specific energy production, as well as system energy output. Simulation was run using SolarGIS - PVplanner simulation, an online simulator for solar PV systems. The software uses Google Web Toolkit web programming technology to integrates numerical simulation models from the latest research with new climate databases [11]. The 
simulator provides assessment results at any selected site online [12]. In simulation for library building, PV system installation on the roofs is divided into 9 segments; each is according to position and orientation (Figure 5).

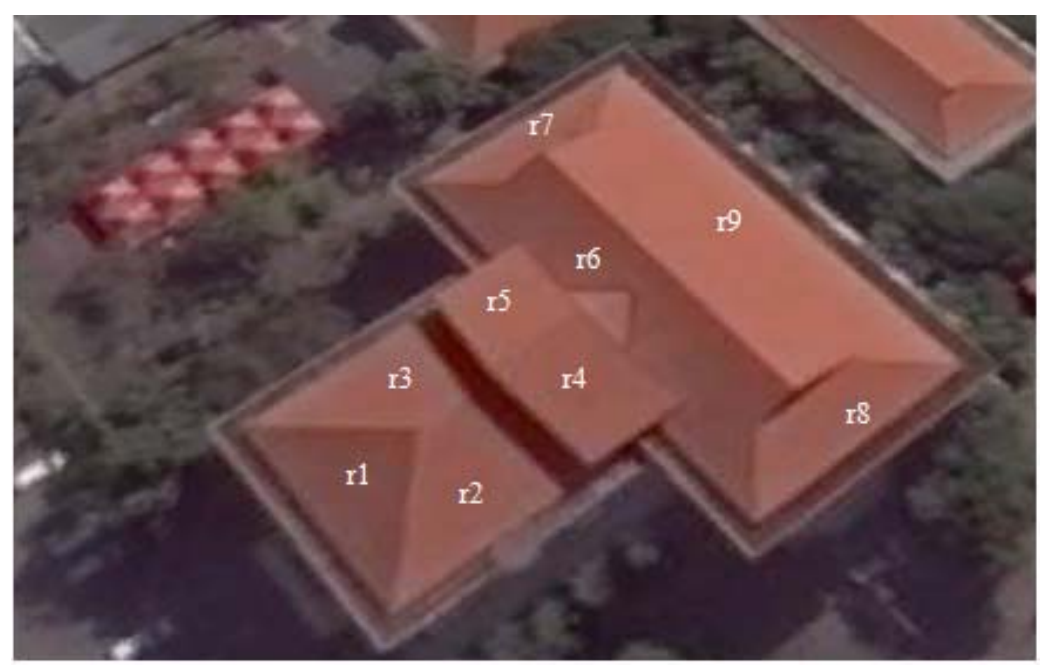

Fig. 5. Roof segments for simulation

\subsection{Unit Cost of Electricity Analysis}

The unit cost of electricity estimation of the designed grid-connected system was calculated following method by previous work [3]. The components that are related to a gridconnected system cost are module cost, balance of system (BOS) cost, system lifetime, discount rate, and operating and maintenance (O\&M) cost. The total cost per peak watt of PV system can be calculated with a derived equation. A numerical calculation could be done to estimate the unit cost of PV electricity. The unit cost of electricity from PV system $\left(C_{p v}\right)$ mathematically can be formulated as:

$$
C_{p v}=\frac{\text { Levelized annual cost }}{\text { Annual electricity output }}
$$

The levelized annual cost of the grid connected PV system consists of annual O\& M costs, the annual cost of capital recovery, insurances, taxes, etc. The annual cost of capital recovery in return can be counted as a component of cost of $C_{c}$ and capital recovery factor with relation [13]:

$$
\text { Annual capital recovery cost }=C_{C}\left[\frac{r(1+r)^{t}}{(1+r)^{t}-1}\right]
$$

Where $C_{c}$ is cost of capital; $r$ is rate of return; and $t$ is the system life time. 
If the component cost of annual O\&M is assumed as a fraction $\mathrm{n}$ of the cost of capital, and the component of taxes, insurance, etc., are assumed as a fraction $m$ of the cost of capital cost, the levelized annual cost can be expressed as :

$$
\text { C annual }=C_{C}\left[\frac{r(1+r)^{t}}{(1+r)^{t}-1}+n+m\right]
$$

From the capacity utilization factor, $F$, of the PV system, The annual electricity output (annual) can be estimated from PV system capacity utilization factor F with equation:

$$
\text { Annual }=(8,760 \mathrm{x} \text { (the PV system at maximum power }) \mathrm{x}(\mathrm{F})
$$

The equation for unit cost of electricity produced by the grid-connected PV system, $C p v$, can be simplified by expressing of the total capital of cost $C c$ as a product of maximum power and the total cost per peak watt, Cpw. The equation can be expressed as:

$$
C p v=\frac{C_{p w}\left[\frac{r(1+r)^{t}}{(1+r)^{t}-1}+n+m\right]}{8,760 F}
$$

Numerical calculation was made using equation 5 for estimating the unit cost of PV electricity.

\section{Results and Discussion}

\subsection{Solar Energy Potential}

The exact location of the university campus (buildings) as indicated an Google Maps ${ }^{\mathrm{TM}}$ is between $7^{\circ} 19^{\prime} 22.98 ”-7^{\circ} 19^{\prime} 04.04^{\prime \prime}$ South and $112^{\circ} 46^{\prime} 22.02^{\prime \prime}-112^{\circ} 22^{\prime} 04.65^{\prime}$. Total area of land of the campus is about $88,020 \mathrm{~m}^{2}$ with about $1535 \mathrm{~m}$ of circumfence. Fig 6 . shows the Sun path in Surabaya (simulated site location) over a year. The sun path figure shows the terrain horizon, module horizon, and active area with solar and civil time. Shading effect on solar radiation might be happen on module horizon.

The variation of the day length and solar zenith angle yearly in Surabaya area is shown in Fig. 8. It is obviously seen that, if obstructed by higher terrain horizon, the time when the Sun is above the horizon (whic is the local day length) is shorter compared to the astronomical day length.

Global horizontal irradiation (which consists of are direct, diffuse and reflected components) is shown in in Fig. 8. The ambient air temperature during a year is also shown in the Figure. It can be seen from the figure that during March - October, the radiation is quite significant dominated with the diffuse component, while reflected radiation relatively small throughout the year. The simulation results shows that, the maximum value of global solar irradiation was $6,81 \mathrm{kWh} / \mathrm{m}^{2}$ with daily average is about $5.54 \mathrm{kWh} / \mathrm{m} 2$ per day during 
September. While less solar irradiation is happen during December, with average of 4,82 $\mathrm{kWh} / \mathrm{m}^{2}$.

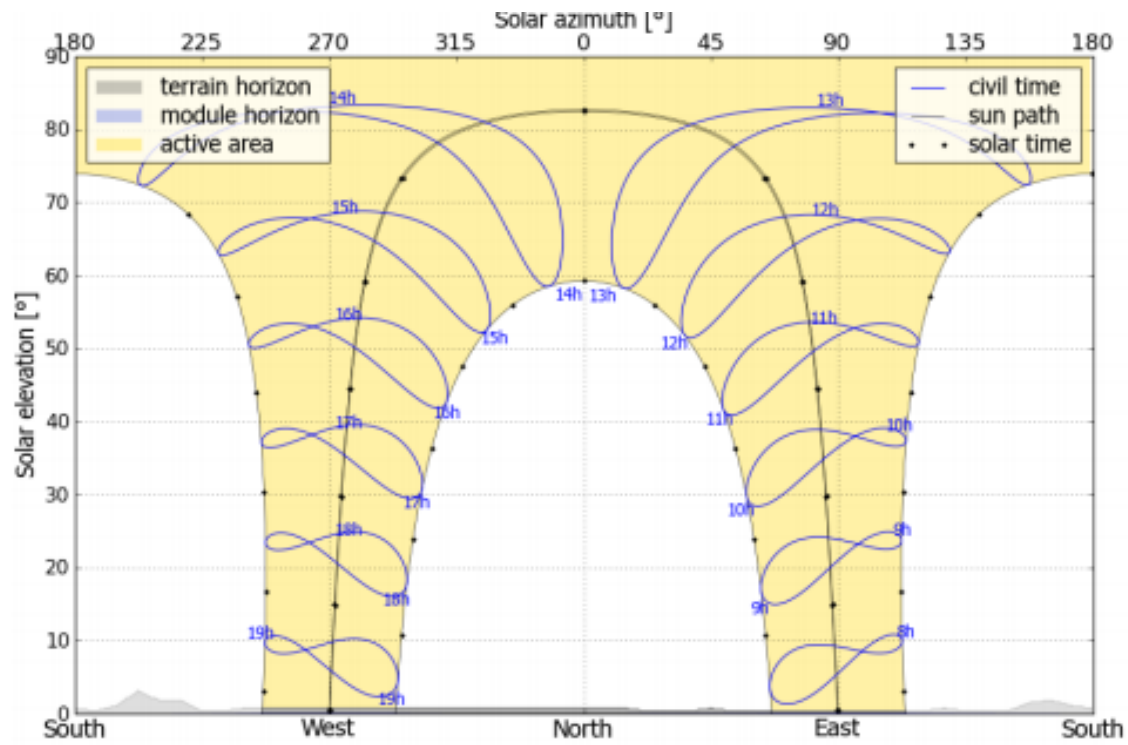

Fig. 6. Sun Path over a year in Surabaya

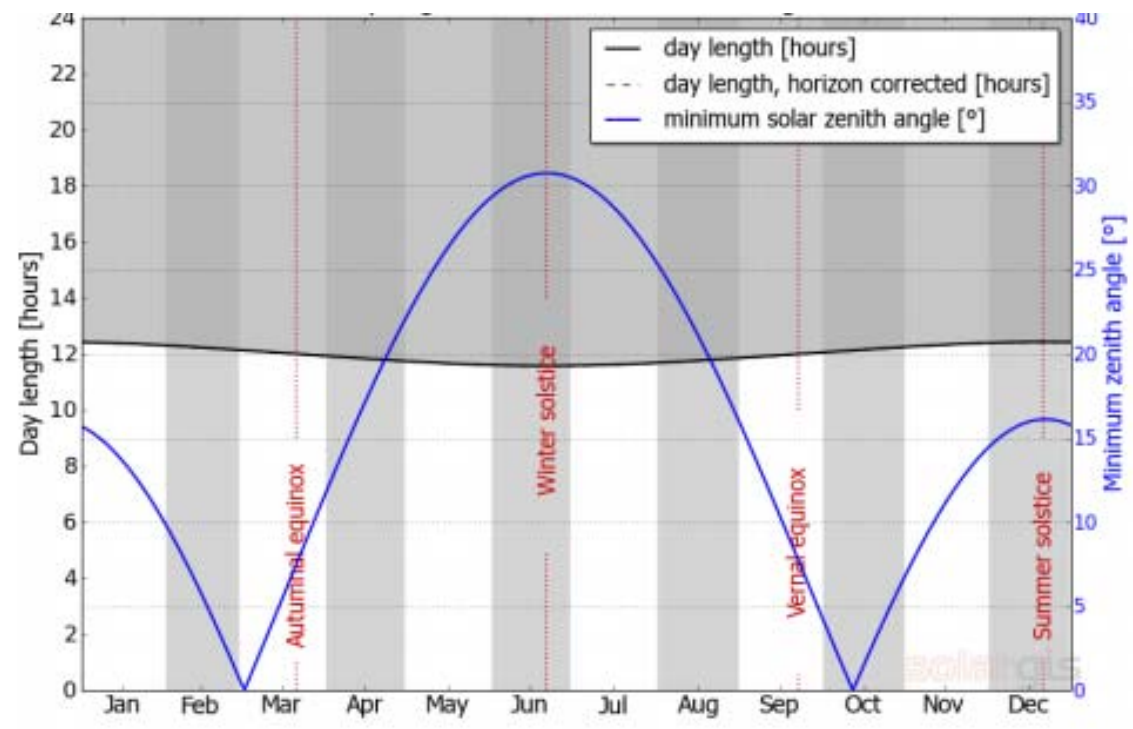

Fig. 7. Solar zenith angle and day length and in Surabaya 


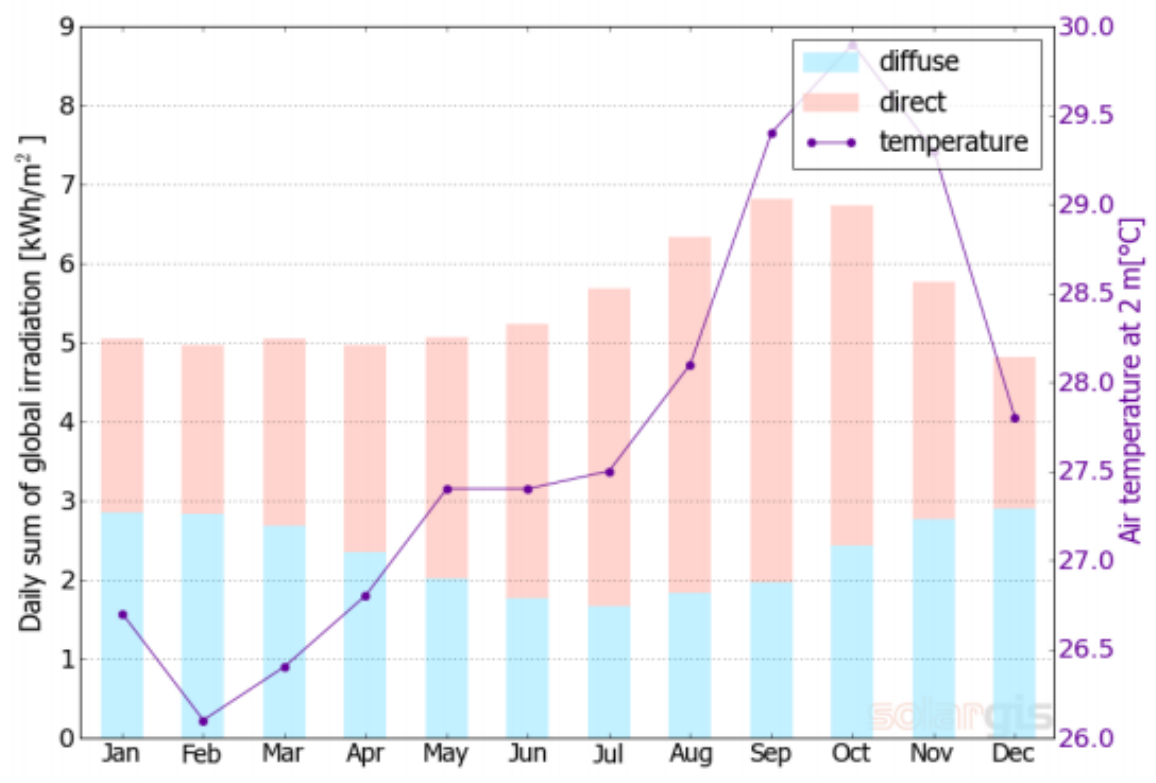

Fig. 8. Global irradiation and air temperature in Surabaya

In past, usually, the global radiation is higher during month April - October than the other months. It can be understood that during this period dry season commonly occur in this region meanwhile rainy season is during December - March which resulted in the lower average solar radiation. However, recently, the season period is likely unpredictable, and further investigation should be attempted for this as it might be closely related not only to the PV application but also to other issues such as global warming or climate change. Daily air temperature in Surabaya varies from $26-31^{\circ} \mathrm{C}$ as as shown in Fig. 8

\subsection{Solar Roof Effective Area}

Total area of the roofs for all buildings of the campus was found about $12,280 \mathrm{~m}^{2}$, means that total the area of the roof is $14 \%$ of the land. It is obviously seen that each of the roof for all buildings consists of four sides. The roof area for each directions were found: North East (NE) with $329 \mathrm{~m}^{2}$ or $26 \%$; South East (SE) with 2731 or $22 \%$, South West (SW) with 3409 or $29 \%$, and North West (NW) 353 or $23 \%$ of total roof area respectively. The area of each side and direction for each building is summarized in Table 2.

Previous study located in Spain reported that useful roof surface area is ranging between $78,9 \%-97,4 \%$ of total roof area, for similar type of roof [14]. In this simulation work the value of $85 \%$ is assumed. The estimated useful area of the roof buildings is shown in the right column on Table 2.

Sitting of the PV panels, using an exported and scaled map image with Google Sketch up software, for the chosen roof of representative building showed that up to $85 \%$ of the roof area could be placed by panels installation. The sitting panels are as illustrated in Figure 3. Estimated useful roof surface area for library building is presented in Table 3. By installing monocristaline PV module parameters the panel capacity the roof could be estimated through simulation. The total capacity of the panels that can be installed on the roof was found about $233.4 \mathrm{kWp}$. 
Table 2. Roof surface area and orientation for buildings of the university campus

\begin{tabular}{|c|c|c|c|c|c|c|c|}
\hline \multirow[t]{2}{*}{ No } & \multirow[t]{2}{*}{$\begin{array}{l}\text { Building's } \\
\text { Name }\end{array}$} & \multirow[t]{2}{*}{$\begin{array}{l}\text { Total } \\
\text { Roof }\end{array}$} & \multicolumn{4}{|c|}{ Roof Area $\left(\mathrm{m}^{2}\right)$ and Orientation } & \multirow[t]{2}{*}{$\begin{array}{l}\text { Estimated Useful } \\
\text { Area }\left(\mathrm{m}^{2}\right)\end{array}$} \\
\hline & & & NE & SE & SW & NW & \\
\hline 1 & EA & 516 & 34 & 224 & 34 & 224 & 439 \\
\hline 2 & EB & 324 & 42 & 120 & 42 & 120 & 275 \\
\hline 3 & EC & 304 & 26 & 126 & 26 & 126 & 258 \\
\hline 4 & ED & 250 & 90 & 35 & 90 & 35 & 213 \\
\hline 5 & FA & 200 & 50 & 50 & 50 & 50 & 170 \\
\hline 6 & $\mathrm{FB}$ & 380 & 140 & 50 & 140 & 50 & 323 \\
\hline 7 & FC & 400 & 40 & 160 & 40 & 160 & 340 \\
\hline 8 & FD & 400 & 160 & 40 & 160 & 40 & 340 \\
\hline 9 & $\mathrm{FE}$ & 440 & 50 & 170 & 50 & 170 & 374 \\
\hline 10 & $\mathrm{FF}$ & 420 & 170 & 40 & 170 & 40 & 357 \\
\hline 11 & FG & 320 & 40 & 120 & 40 & 120 & 272 \\
\hline 12 & HA & 420 & 170 & 40 & 170 & 40 & 357 \\
\hline 13 & HB & 408 & 142 & 62 & 142 & 62 & 347 \\
\hline 14 & TA & 340 & 30 & 140 & 30 & 140 & 289 \\
\hline 15 & TB & 400 & 160 & 40 & 160 & 40 & 340 \\
\hline 16 & $\mathrm{TC}$ & 480 & 40 & 200 & 40 & 200 & 408 \\
\hline 17 & TD & 360 & 140 & 40 & 140 & 40 & 306 \\
\hline 18 & TE & 360 & 140 & 40 & 140 & 40 & 306 \\
\hline 19 & $\mathrm{TF}$ & 360 & 140 & 40 & 140 & 40 & 306 \\
\hline 20 & TG & 420 & 40 & 170 & 40 & 170 & 357 \\
\hline 21 & PA & 280 & 40 & 100 & 40 & 100 & 238 \\
\hline 22 & PB & 330 & 130 & 35 & 130 & 35 & 281 \\
\hline 23 & PC & 480 & 200 & 40 & 200 & 40 & 408 \\
\hline 24 & PD & 380 & 160 & 30 & 160 & 30 & 323 \\
\hline 25 & $\mathrm{PE}$ & 380 & 160 & 30 & 160 & 30 & 323 \\
\hline 26 & Library & 1400 & 373 & 187 & 563 & 277 & 1.190 \\
\hline 27 & Canteen & 560 & 130 & 150 & 130 & 150 & 476 \\
\hline 28 & Int. & 408 & 142 & 62 & 142 & 62 & 347 \\
\hline 29 & Post grad. & 460 & 40 & 190 & 40 & 190 & 391 \\
\hline
\end{tabular}

Table 3. Roof segment energy potential for library building

\begin{tabular}{ccccc}
\hline Segment & Orientation & $\begin{array}{c}\text { Total Roof } \\
\text { Area }\left(\mathrm{m}^{2}\right)\end{array}$ & $\begin{array}{c}\text { Estimated Useful } \\
\text { Area }\left(\mathrm{m}^{2}\right)\end{array}$ & $\begin{array}{c}\text { Estimated PV panels } \\
\text { Capacity (Wp) }\end{array}$ \\
\hline r1 & SW & 100 & 85 & 16.660 \\
r2 & SE & 104 & 88 & 17.248 \\
r3 & NW & 104 & 88 & 17.248 \\
r4 & SW & 90 & 77 & 15.092 \\
r5 & NW & 90 & 77 & 15.092 \\
r6 & SW & 373 & 317 & 62.132 \\
r7 & NW & 83 & 71 & 13.916 \\
r8 & SE & 83 & 71 & 13.916 \\
r9 & NE & 373 & 317 & 62.132 \\
& & & & Total: 233.436 \\
& & & &
\end{tabular}

The total PV panels capacity of the roof for all buildings of University of Surabaya then could be estimated using the numbers from Table 2 and from simulation results for library building on Table 3 . Calculation showed that, of $12,180 \mathrm{~m}^{2}$ roof area for all buildings, about $10,353 \mathrm{~m}^{2}$ could be use for panels installation. The total capacity of the panels is about 2,030 
$\mathrm{kWp}$ or 2,03 MWp. The capacity consists of four roof directions, i.e., $630 \mathrm{kWp}, 535 \mathrm{kWp}, 668$ $\mathrm{kWp}$ and $553 \mathrm{kWp}$ respectively for NE, SE, SW and NW roof directions.

\section{3 PV Specific Energy Production}

SolarGIS-pvPlanner simulation was carried out to estimate the specific energy production of the PV system in Surabaya by varying solar geometry parameters. Table 5 shows the the specific energy production of a crystalline silicon based PV system in Surabaya. In the Table Esm refers monthly sum of specific electricity production in $\mathrm{kWh} / \mathrm{kWp}$; while Esd is daily sum of specific electricity production in $\mathrm{kWh} / \mathrm{kWp}$. The results in the table is for each for each of panel orientation of : azimuth of $315^{\circ}(\mathrm{NW}), 45^{\circ}(\mathrm{NE}), 225^{\circ}(\mathrm{SW})$, and $135^{\circ}$ (SE) with inclination $5^{\circ}, 13^{\circ}, 0^{\circ}$ respectively. It is assumed that mounted system is the most suitable for the roof instalation [10] .

Table 4. Specific Energy production of PV system in Surabaya with variation of azimuth angle

\begin{tabular}{|c|c|c|c|c|c|c|c|c|}
\hline \multirow[t]{2}{*}{ Month } & \multicolumn{2}{|c|}{$\begin{array}{c}\text { Azim. } 315^{\circ} \\
\text { (northwest), } \\
\text { incl. } 5^{\circ}\end{array}$} & \multicolumn{2}{|c|}{$\begin{array}{c}\text { Azim. } 45^{\circ} \\
\text { (northeast), } \\
\text { incl. } 13^{\circ}\end{array}$} & \multicolumn{2}{|c|}{$\begin{array}{c}\text { Azim. } 225^{\circ} \\
\text { (southwest), } \\
\text { incl. } 0^{\circ}\end{array}$} & \multicolumn{2}{|c|}{$\begin{array}{l}\text { Azim. } 135^{\circ} \\
\text { (southeast), } \\
\text { incl. } 0^{\circ}\end{array}$} \\
\hline & Esm & Esd & Esm & Esd & Esm & Esd & Esm & Esd \\
\hline Jan & 116 & 3.75 & 115 & 3.73 & 117 & 3.79 & 117 & 3.79 \\
\hline Feb & 104 & 3.73 & 104 & 3.74 & 104 & 3.74 & 104 & 3.74 \\
\hline Mar & 118 & 3.83 & 120 & 3.89 & 117 & 3.79 & 117 & 3.79 \\
\hline Apr & 114 & 3.82 & 117 & 3.93 & 111 & 3.72 & 111 & 3.72 \\
\hline May & 122 & 3.94 & 127 & 4.11 & 117 & 3.79 & 117 & 3.79 \\
\hline Jun & 123 & 4.12 & 129 & 4.32 & 117 & 3.92 & 117 & 3.92 \\
\hline Jul & 138 & 4.45 & 144 & 4.65 & 131 & 4.23 & 131 & 4.23 \\
\hline Aug & 150 & 4.86 & 154 & 5.00 & 144 & 4.67 & 144 & 4.67 \\
\hline Sep & 152 & 5.09 & 154 & 5.15 & 148 & 4.95 & 148 & 4.95 \\
\hline Oct & 153 & 4.95 & 152 & 4.92 & 151 & 4.89 & 151 & 4.89 \\
\hline Nov & 126 & 4.20 & 124 & 4.16 & 126 & 4.22 & 126 & 4.22 \\
\hline Dec & 109 & 3.55 & 109 & 3.52 & 111 & 3.59 & 111 & 3.59 \\
\hline Year & 1530 & 4.19 & 1555 & 4.26 & 1500 & 4.11 & 1500 & 4.11 \\
\hline
\end{tabular}

From the simulation, it was found daily average specific energy production for crystalline silicon panel for each direction and, by setting $35^{\circ}$ tilted panels as shown in Table 5 . The tilt angle was chosen following the slope of the roof. Changing of PV panel type in simulation parameter resulted in slightly different results. For all cases the panel facing NE would produce the highest energy. It can be understood as Surabaya is located at South of equator line.

Monthly energy production of grid connected PV system could be estimated using the specific energy production values and the roof panel capacity. For an optimistic case, where all of available roof at the university would be installed by PV panels, monthly energy production would be ranging from $248 \mathrm{mWh}$ to $362 \mathrm{mWh}$ per month. The numbers are after the shading lost of $2 \%[9]$, as previously mentioned, has been included in the calculation. Figure 9 shows total monthly energy production come from total of roofs facing SE, SW, NE, and NW respectively. 
Table 5. Daily specific energy production in $\mathrm{kWh} / \mathrm{kWp}$ of Silicon PV Panels in Surabaya following the roof tilt.

\begin{tabular}{lccccccccccccc}
\hline & Jan & Feb & Mar & Apr & May & Jun & Jul & Aug & Sept & Oct & Nov & Dec & Avg \\
\hline NW & 3.75 & 3.73 & 3.83 & 3.82 & 3.94 & 4.12 & 4.45 & 4.86 & 5.09 & 4.95 & 4.20 & 3.55 & 4.19 \\
NE & 3.73 & 3.74 & 3.89 & 3.93 & 4.11 & 4.32 & 4.65 & 5.00 & 5.15 & 4.92 & 4.16 & 3.52 & 4.26 \\
SE & 3.79 & 3.74 & 3.79 & 3.72 & 3.79 & 3.92 & 4.23 & 4.67 & 4.95 & 4.89 & 4.22 & 3.59 & 4.11 \\
SW & 3.79 & 3.74 & 3.79 & 3.72 & 4.79 & 4.92 & 4.23 & 4.67 & 4.95 & 4.89 & 4.22 & 3.59 & 4.11 \\
\hline
\end{tabular}

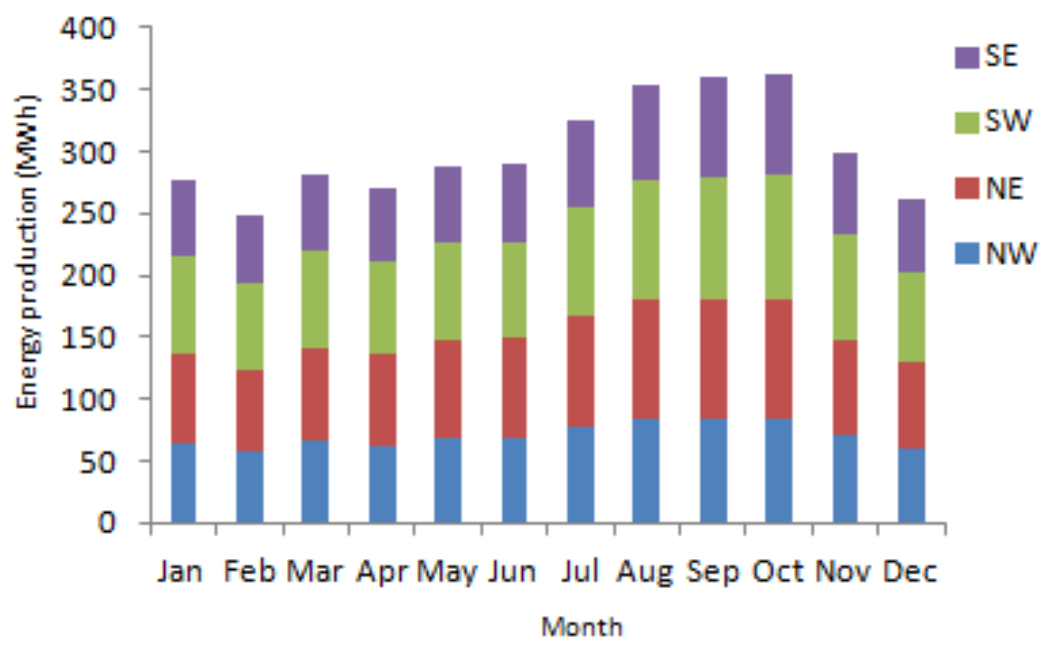

Fig. 9. Monthly energy production of rooftops mounted PV system

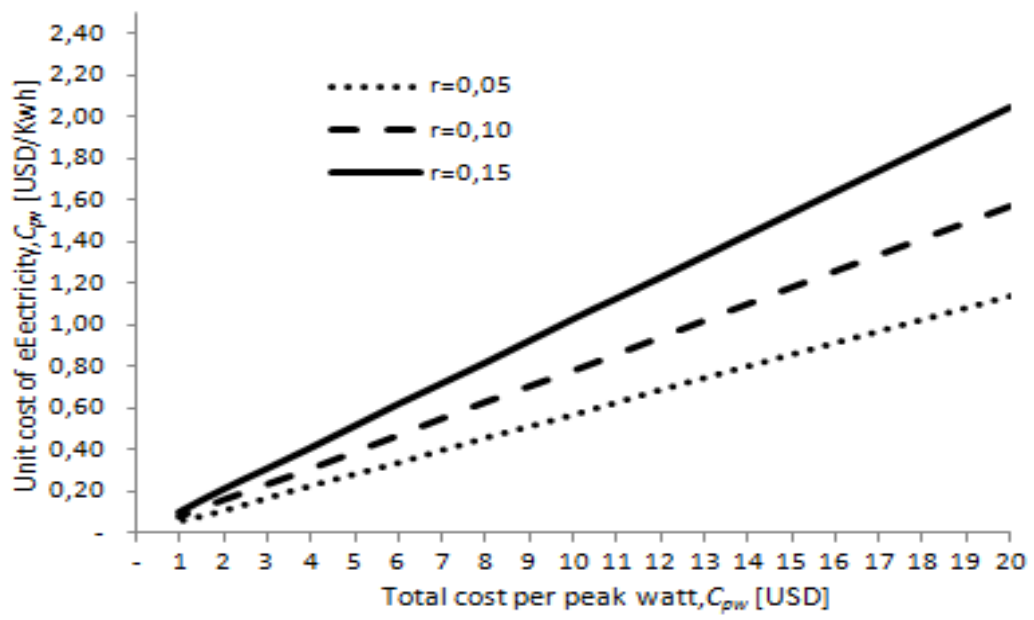

Fig. 10. The unit cost of PV electricity versus total cost per watt with various of rate of return, $r$ 


\subsection{Economic Analysis}

Equation 5 was using to make a numerical calculation to estimate real unit cost of PV electricity. In the calculations the following parameters values were considered: $t=20$ years, $n$ $=5 \%, F=20 \%$, and $\mathrm{m}=0$ and simulated for four scenarios of $r$ i.e., $0.05,0.10$, and 0.15 respectively. The result of calculation is plotted in a graph as shown in Figure 10. With conversion value from the graph, at present time the means the unit cost of electricity $C p w$ is range $0.20-0.40 \mathrm{USD} / \mathrm{kWh}$. For comparison, currently feed-in tariffs for solar PV electricity in Indonesia is $0.25 \mathrm{USD} / \mathrm{kWh}$.

\section{Conclusions}

Photovoltaic solar energy simulation of rooftops of University of Surabaya campus buildings in Surabaya, Indonesia has been carried out. Total area of the roofs for all buildings of the campus was found about $12,280 \mathrm{~m} 2$. The roofs consist of area from four different direction: North East (NE) with $329 \mathrm{~m} 2$ or $26 \%$; South East (SE) with 2731 or $22 \%$, South West (SW) with 3409 or $29 \%$, and North West (NW) 353 or $23 \%$ of total roof area respectively. The total capacity of the panels that could be installed is about 2,030 kWp or 2,03 MWp with monthly energy production would range from $248 \mathrm{mWh}$ to $362 \mathrm{mWh}$ per month. From the calculation of unit cost of electricity by PV systems, it is obviously seen that PV system seem have the potential to provide power at competitive cost in comparison to other alternative options of power generation, especially through the technology developments.

\section{References}

[1]A. Benatiallah, R. Mostefaoui, M. Boubekri, and N. Boubekri, “A simulation model for sizing PV installations,” Desalination, vol. 209, no. 1, pp. 97-101, 2007.

[2]A. Orioli and A. Di Gangi, "Review of the energy and economic parameters involved in the effectiveness of grid-connected PV systems installed in multi-storey buildings,” Appl. Energy, vol. 113, pp. 955-969, 2014.

[3]E. Tarigan, Djuwari, and F. D. Kartikasari, "Techno-economic Simulation of a Gridconnected PV System Design as Specifically Applied to Residential in Surabaya, Indonesia,” Energy Procedia, vol. 65, pp. 90-99, 2015.

[4]L. Ko, J. C. Wang, C. Y. Chen, and H. Y. Tsai, "Evaluation of the development potential of rooftop solar photovoltaic in Taiwan,” Renew. Energy, vol. 76, pp. 582-595, 2015.

[5]L. K. Wiginton, H. T. Nguyen, and J. M. Pearce, "Quantifying rooftop solar photovoltaic potential for regional renewable energy policy,” Comput. Environ. Urban Syst., vol. 34, no. 4, pp. 345-357, 2010.

[6]R. Vardimon, “Assessment of the potential for distributed photovoltaic electricity production in Israel,” Renew. Energy, vol. 36, no. 2, pp. 591-594, 2011.

[7]L. Bergamasco and P. Asinari, "Scalable methodology for the photovoltaic solar energy potential assessment based on available roof surface area: Application to Piedmont Region (Italy),” Sol. Energy, vol. 85, no. 5, pp. 1041-1055, 2011.

[8]S. Kuchler, "Solar Energy Assesment Based on Weather Station Data for Direct Site 
Monitoring in Indonesia,” Dalarna University, 2013.

[9]H. T. Nguyen and J. M. Pearce, "Incorporating shading losses in solar photovoltaic potential assessment at the municipal scale,” Sol. Energy, vol. 86, no. 5, pp. 1245-1260, 2012. [10]E. Tarigan, Djuwari, and L. Purba, “Assessment of PV Power Generation for Household in Surabaya Using SolarGIS-pvPlanner Simulation,” Energy Procedia, vol. 47, pp. 85-93, 2014.

[11]Marcel S. \& Tomáš C., "New Web-Based Service Offering Solar Radiation Data and PV Simulation Tools for Europe, North Africa and Middle East,” in Eurosun, 2012. [12]SolarGis, "SolarGis PVPlanner.” [Online]. Available: http://solargis.info/pvplanner. [Accessed: 20-Jun-2006].

[13]Kandpal T.C. and Garg H.P., Financial evaluation of renewable energy technologies. 2003.

[14]J. Ordez, E. Jadraque, J. Alegre, and G. Mart??nez, “Analysis of the photovoltaic solar energy capacity of residential rooftops in Andalusia (Spain),” Renew. Sustain. Energy Rev., vol. 14, no. 7, pp. 2122-2130, 2010. 